\title{
An assessment of the performance of different districts towards Sustainable Development targets in India
}

\author{
Priyanka Tiwari $^{1^{*}}$, Mayank Krishna ${ }^{2}$ \\ ${ }^{1}$ Centre for the Study of Regional Development, School of Social Sciences, Jawaharlal Nehru \\ University, New Delhi-110067, India \\ * corresponding author: tiwaripriyan@gmail.com \\ ${ }^{2}$ School of Environmental Sciences, Jawaharlal Nehru University, New Delhi-110067, India
}

Received: 16 April 2020 / Accepted: 28 May 2020

\begin{abstract}
Sustainable development goals encapsulates 17 broad-based goals and 169 associated targets to reconcile among the three pillars of sustainability i.e. social, economic and environmental. In the present study, we sought to understand the performance of 641 districts of India on social, economic and environmental parameters and on the composite sustainability index as a whole. Our results suggest that there is a large regional variations in performance with districts of southern and western states outperforming northern and eastern states on sustainability index. There is a strong congruence between social and economic indicators. However, environment is still missing from the policy planning. Our results may provide a benchmark and help in micro-level planning at district level and may help in raising public and policy support, realignment and reorientation of the existing policy from the perspective of SDGs.
\end{abstract}

Keywords: districts of India, economic index, social index, environment, Sustainable Development Goals, indicators.

\section{Introduction}

Sustainable development goals (SDGs) primarily aim to reconcile among the three pillars of development i.e. social, economic and environmental (Harris, 2000). SDGs encapsulate 17 broad-based goals and associated 169 targets in an integrated way (Bossel, 1999; J.R. De, 1992; Le Blanc, 2015; Hák et al., 2016). These set of goals were adopted by the United Nations (UN) in 2015 with targets to be achieved by 2030. United Nations (UN) agenda-2030 focuses on three dimensions envisioned to reconcile the legitimate immediate demands of the present generation with the generations yet unborn (WCED, 1987). However, success in achieving the charted goals hinge on understanding the interactions between goals and targets and managing the trade-offs between them (Lélé, 1991; Lafferty, 2000; Kates et al, 2005).

Within the SDGs framework various targets and goals may interact synergistically wherein achievement of one target consequently lead to the achievement of multiple goals and targets. Alternatively, SDGs also involve various trade-offs, wherein achievement of one goal or target has negative consequences on meeting other set of targets or goals (Taylor, 
2002; Hák et al., 2016). For e.g. the conflict between energy provision and climate change regulation. Mitigating climate change (SDGs 13) requires an increase in share of renewable energy sources (Goal 7) such as biofuels, which might have a negative consequence on secured access to food. Understanding such nuances of interactions among different goals are crucial for achieving SDGs. Additionally, it is also important to identify various impediments in meeting different targets and goals for proper realization of sustainable development (Mebratu, 1998; Bai et al., 2010; Kwatra et al., 2016).

Countries like India with younger generation forming the largest share of population with varied social and economic aspirations is a signatory of SDGs and an important key to the achievement of charted goals. However, achievement of SDGs in India is fettered by various constraints due to the existing socio-economic gradient that varies with different regions within the country. The existing gradients are the major impediments in deducing a logical set of indicators in tracking the progress towards achievement of set goals (Biggs et al., 2011; Kwatra et al., 2016).

India with a diverse landscape incorporates variations at all levels such as agroclimatic, social, economic, environmental etc. It is necessary to adopt bottom-to-top approach and policy formulation at local levels for actual realization of SDGs. In this context, the prime focus of the present study is to analyse the performance of different districts in India on individual pillars of the sustainable development and sustainability as a whole.

The specific objectives of the present study are to (1) calculate a composite index using different sets of indicator in individual domain i.e. social, economic and environment and sustainability as whole. (2) provide a benchmark to the policy makers for improvement of sustainability in regions lagging behind in realisation of SDGs.

\section{Materials and Methods}

\subsection{Study domain}

India is a tropical country lying between $6^{\circ} 44^{\prime} \mathrm{N}$ and $68^{\circ} 07^{\prime} \mathrm{E}$ and $68^{\circ} 07^{\prime} \mathrm{E}$ and $97^{\circ} 25^{\prime} \mathrm{E}$ with a total area of $3,287,263 \mathrm{~km}^{2}$. It is bounded by the Indian Ocean in south, Arabian sea in southwest, and the Bay of Bengal in its southeast. As per the administrative division, India is composed of 29 states and 7 union territories, (including a national capital territory). The states and territories are further subdivided into 641 districts. Districts are the local administrative units and are the focus of the study. Districts are the part of local government and forms the basic administrative unit for the matters related to policy planning and 
management. The country's district wise administrative boundaries delineation is shown in Figure 1.

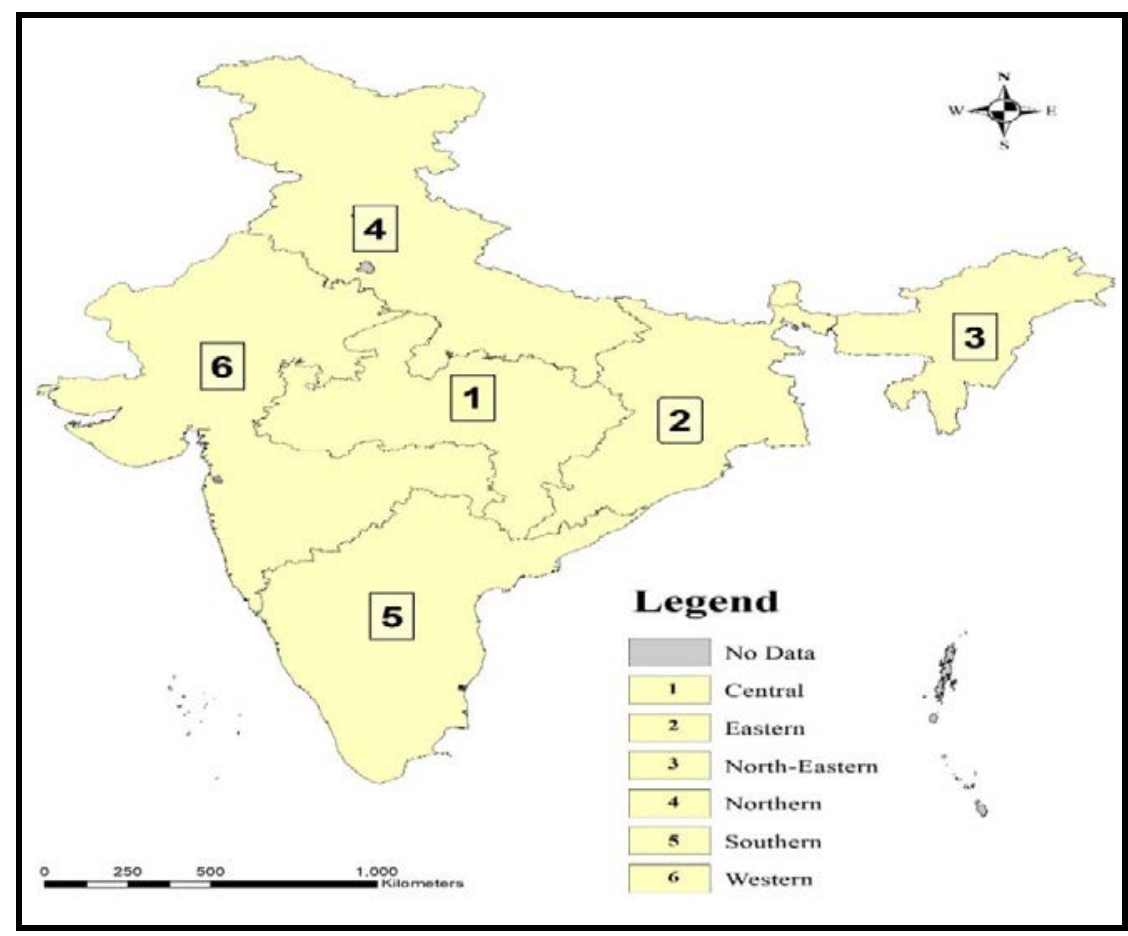

Figure 1. Study domain and district wise administrative boundaries delineation (Source:

Census of India, 2011)

\section{2. Methodology}

We analysed performance of all districts on sustainability on individual parameters i.e. social, economic and environmental using different sets of indicators. Finally, a composite index defining sustainability was prepared for each district (Biggs \& Rogers, 2003; Bandura, 2008; Dahl, 2012). A correlation matrix was generated to understand and analyse the interrelationship among different indicators. Further, interrelationships among different indicators were ranked in three different categories based on the correlation coefficient (r) i.e. feebly correlated $(0.4<\mathrm{r}<0.5)$, moderately correlated $(0.5<\mathrm{r}<0.6)$, and strongly correlated ( $r>0.6)$ following Kwatra et al (2016).

Since the indicators covering three parameters i.e. social, economic and environment had different units of measurement it was normalized using Z-score to make it comparable. The formula used for Z-score normalization was 


\section{$\mathrm{Z}_{\text {score }}=\frac{\boldsymbol{X}_{\tilde{i}-\text { Mean }}}{\text { Std.Dev. }}$}

Henceforth, Z score values of each indicator was averaged to derive environmental, social, economic indices following Kwatra et al. (2016).

Environmental index $\left(\mathrm{Z}_{\text {Env }}\right)$ :

$$
\left(Z_{\text {env }}\right)=\frac{\sum_{i}^{n} \bar{m} A_{i}}{n}
$$

Social index $\left(\mathrm{Z}_{\text {Soc }}\right)$ :

$$
\left(Z_{S o c}\right)=\frac{\sum_{i}^{n} B_{i}}{n}
$$

Economic index $\left(\mathrm{Z}_{\mathrm{Eco}}\right)$ :

$$
\left(Z_{\text {eco }}\right)=\frac{\sum_{i}^{n} \bar{I} C_{i}}{n}
$$

where A, B, C were the indicators of environment, social and economic, respectively.

The performance of every district in environmental, social and economic dimensions were compared and evaluated using the prepared index.

Finally, Sustainability development index (SDI):

$$
S D I=\frac{Z_{\text {env }}+Z_{\text {soc }}+Z_{\text {exco }}}{3}
$$

was calculated taking the mean of the environment, social and economic indices for each districts.

\section{3 Data description}

For analysis, the datasets were compiled from Census of India, 2011 (http://censusindia.gov.in/), and other published government reports. The collected datasets were assembled under different parameters. The list of indicators under different parameters , data sources and rationale behind selection of indicators in addition to their positive or negative effect on sustainability is detailed in Table 1. 
Table 1. Themes, parameters, indicators, rationale for the selection of indicators

\begin{tabular}{|c|c|c|c|c|c|}
\hline Theme & Parameter & Indicator & Equation & Rational for selection & $\begin{array}{l}\text { Positive/Negative } \\
\text { for sustainability }\end{array}$ \\
\hline \multirow{5}{*}{ 苞 } & Forest $^{1}$ & $\begin{array}{l}\text { Percent of } \\
\text { forest in total } \\
\text { geographical } \\
\text { area }\end{array}$ & $\begin{array}{l}\text { Total forest cover/total } \\
\text { geographical area } \times 100\end{array}$ & $\begin{array}{l}\text { National forest policy } \\
\text { aims at maintaining of } \\
\text { minimum of } 33 \% \text { of } \\
\text { country's geographical } \\
\text { area under forest. }\end{array}$ & Positive \\
\hline & Scrub $^{1}$ & $\begin{array}{l}\text { Percent of } \\
\text { scrub }\end{array}$ & $\begin{array}{l}\text { Total scrub/total } \\
\text { geographical area } \times 100\end{array}$ & $\begin{array}{l}\text { Scrub is important for } \\
\text { sustainability as it binds } \\
\text { soil, and prevents soil } \\
\text { erosion. }\end{array}$ & Positive \\
\hline & Land $^{1}$ & $\begin{array}{l}\text { Total } \\
\text { wasteland area }\end{array}$ & $\begin{array}{l}\text { Total wasteland } \\
\text { area/Total } \\
\text { geographical area } \times 100\end{array}$ & $\begin{array}{l}\text { Wasteland refers to land } \\
\text { which lack quality of } \\
\text { soil, and suitable for } \\
\text { vegetation condition, it } \\
\text { is incapable of producing } \\
\text { material or any services } \\
\text { of value. }\end{array}$ & Negative \\
\hline & Biodiversity $^{1}$ & $\begin{array}{l}\text { Percent of } \\
\text { protected areas }\end{array}$ & $\begin{array}{l}\text { Pro_areas/total } \\
\text { geographical area } \times 100\end{array}$ & $\begin{array}{l}\text { Biodiversity depicts the } \\
\text { priority given by } \\
\text { government at national, } \\
\text { state and district level to } \\
\text { conserve biodiversity }\end{array}$ & Positive \\
\hline & Ground water $^{2}$ & $\begin{array}{l}\text { ground water } \\
\text { in meters }\end{array}$ & $\begin{array}{l}\text { Ground water in } \\
\text { metres }\end{array}$ & $\begin{array}{l}\text { Groundwater is naturally } \\
\text { replenished by surface } \\
\text { water from precipitation, } \\
\text { streams, and rivers when } \\
\text { this recharge reaches } \\
\text { the water table. }\end{array}$ & Positive \\
\hline \multirow[b]{2}{*}{ 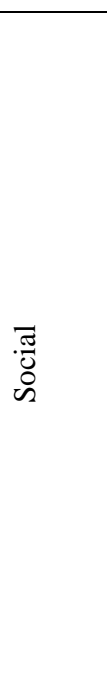 } & Health $^{3}$ & $\begin{array}{l}\text { Number of sub } \\
\text { centres }\end{array}$ & $\begin{array}{l}\text { sub_centre/total } \\
\text { pop } \times 10000\end{array}$ & $\begin{array}{l}\text { Sub-Centre is the most } \\
\text { peripheral and first } \\
\text { contact point between } \\
\text { the primary health care } \\
\text { system and the } \\
\text { community }\end{array}$ & Positive \\
\hline & & $\begin{array}{l}\text { Number of } \\
\text { primary health } \\
\text { centres }\end{array}$ & $\begin{array}{l}\text { pri_health/total } \\
\text { pop } \times 10000\end{array}$ & $\begin{array}{l}\text { Primary health } \\
\text { care refers to the } \\
\text { essential health } \\
\text { care made accessible to } \\
\text { individuals in a } \\
\text { community at costs that } \\
\text { they can afford }\end{array}$ & Positive \\
\hline
\end{tabular}




\begin{tabular}{|c|c|c|c|c|}
\hline & $\begin{array}{l}\text { Number of } \\
\text { community } \\
\text { Health centres }\end{array}$ & $\begin{array}{l}\text { community } \\
\text { centres/total } \\
\text { population } \times 10000\end{array}$ & $\begin{array}{l}\text { A community health } \\
\text { centre is publicly funded } \\
\text { and offers a range } \\
\text { of health services to } \\
\text { local residents. }\end{array}$ & Positive \\
\hline & $\begin{array}{l}\text { Number of } \\
\text { district } \\
\text { hospitals }\end{array}$ & $\begin{array}{l}\text { dist hosp/total } \\
\text { population } \times 10000\end{array}$ & $\begin{array}{l}\text { A district } \\
\text { hospital typically is the } \\
\text { major health care facility } \\
\text { in its region, with large } \\
\text { numbers of beds for } \\
\text { intensive care and } \\
\text { additional beds for } \\
\text { patients who need long- } \\
\text { term care }\end{array}$ & Positive \\
\hline Education $^{3}$ & Literacy rate & $\begin{array}{l}\text { literate } \\
\text { population/total } \\
\text { population } \times 100\end{array}$ & $\begin{array}{l}\text { Literacy rate leads to } \\
\text { enhancement of a } \\
\text { country's human capita. }\end{array}$ & Positive \\
\hline & $\begin{array}{l}\text { Number of } \\
\text { primary } \\
\text { schools }\end{array}$ & $\begin{array}{l}\text { pri_sch/total } \\
\text { population } \times 10000\end{array}$ & $\begin{array}{l}\text { A primary school is a } \\
\text { school which offers } \\
\text { elementary education to } \\
\text { children for good } \\
\text { foundation. }\end{array}$ & Positive \\
\hline & $\begin{array}{l}\text { Number of } \\
\text { senior schools }\end{array}$ & $\begin{array}{l}\text { sr_sch/total } \\
\text { pop } \times 10000\end{array}$ & $\begin{array}{l}\text { it is up gradation of } \\
\text { primary schools, in some } \\
\text { schools esp. private it is } \\
\text { part of primary schools }\end{array}$ & Positive \\
\hline & $\begin{array}{l}\text { Number of } \\
\text { senior } \\
\text { secondary } \\
\text { schools }\end{array}$ & $\begin{array}{l}\text { sr_sec_sch/total } \\
\text { pop } \times 10000\end{array}$ & $\begin{array}{l}\text { It is final form of formal } \\
\text { education which student } \\
\text { can get from schools } \\
\text { before entering higher } \\
\text { education. }\end{array}$ & Positive \\
\hline Demographic $^{3}$ & $\begin{array}{l}\text { Decadal } \\
\text { growth rate }\end{array}$ & $\begin{array}{l}\text { pop(11)- } \\
\text { pop(01)/pop(01) ×100 }\end{array}$ & $\begin{array}{l}\text { the more the growth rate, } \\
\text { it acts as detrimental to } \\
\text { country's development, } \\
\text { because carrying } \\
\text { capacity of any resources } \\
\text { is at certain level }\end{array}$ & Negative \\
\hline & Sex ratio & $\begin{array}{l}\text { total female/total } \\
\text { male } \times 1000\end{array}$ & $\begin{array}{l}\text { Favourable SR leads to } \\
\text { gender balance. }\end{array}$ & Positive \\
\hline & Child SR_0-6 & $\begin{array}{l}\text { total female } 0-6 / \text { total } \\
\text { male } 0-6 \times 1000\end{array}$ & $\begin{array}{l}\text { Favourable Child SR } \\
\text { leads to gender balance. }\end{array}$ & Positive \\
\hline
\end{tabular}




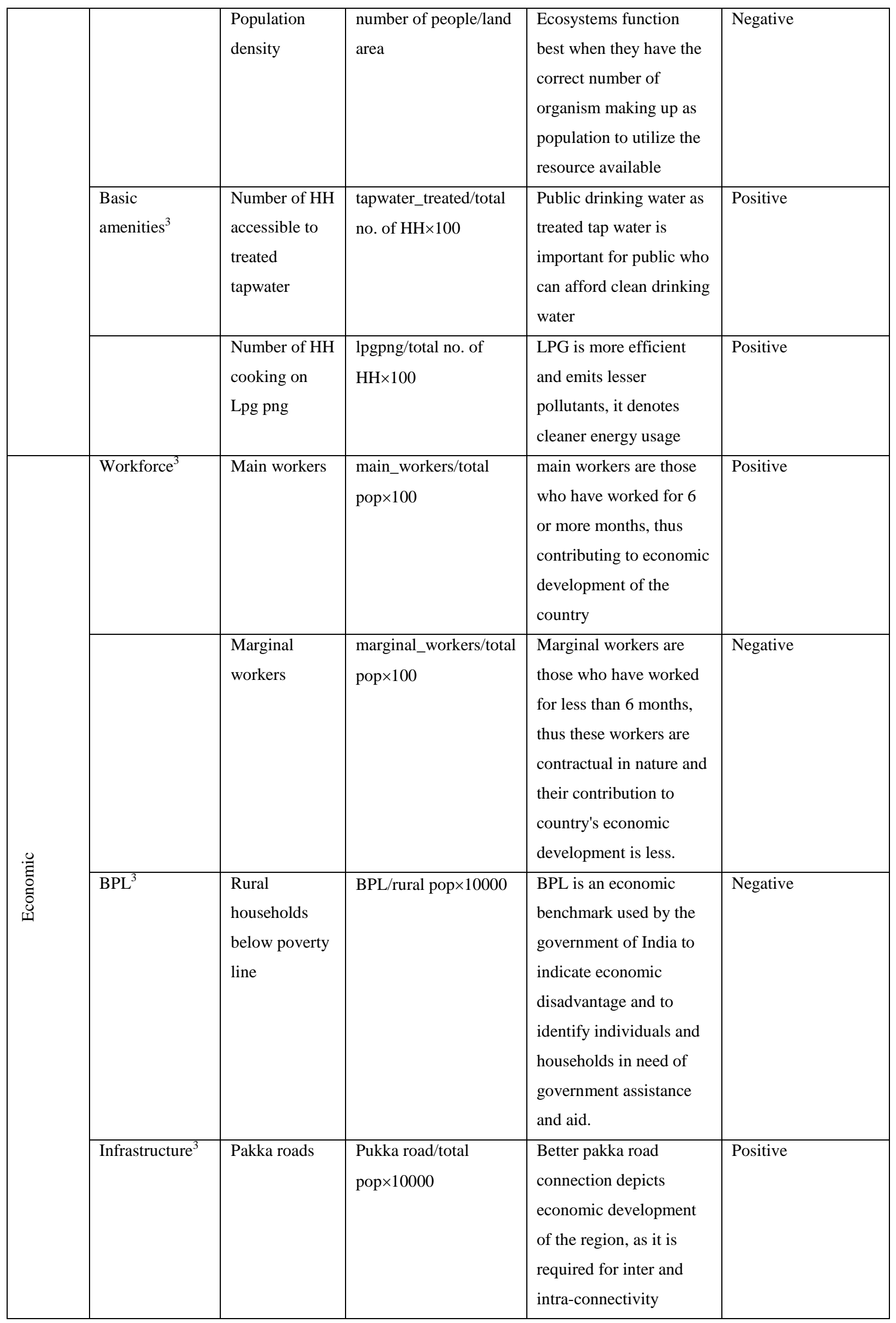




\begin{tabular}{|c|c|c|c|c|}
\hline & & & $\begin{array}{l}\text { between the regions, } \\
\text { hence better } \\
\text { transportation. }\end{array}$ & \\
\hline & $\begin{array}{l}\text { Number of } \mathrm{HH} \\
\text { accessible to } \\
\text { electricity } \\
\text { (light) }\end{array}$ & $\begin{array}{l}\text { Electricity in } \mathrm{HH} / \text { total } \\
\text { no. of } \mathrm{HH} \times 100\end{array}$ & $\begin{array}{l}\text { Almost all the devices at } \\
\text { homes, businesses and } \\
\text { industries are running } \\
\text { because of electricity }\end{array}$ & Positive \\
\hline & $\begin{array}{l}\text { Number of } \mathrm{HH} \\
\text { accessible to } \\
\text { bank services }\end{array}$ & $\begin{array}{l}\text { total banks/total no. of } \\
\mathrm{HH} \times 100\end{array}$ & $\begin{array}{l}\text { bank services provide } \\
\text { financial inclusion to the } \\
\text { region }\end{array}$ & Positive \\
\hline $\begin{array}{l}\text { Mode of } \\
\text { Transportation }\end{array}$ & Two wheeler & $\begin{array}{l}\text { bicycle_moped/total } \\
\text { no. of } \mathrm{HH}^{*} 100\end{array}$ & $\begin{array}{l}\text { Mode of transportation is } \\
\text { important tool for } \\
\text { sustainability. }\end{array}$ & Positive \\
\hline & Four Wheeler & $\begin{array}{l}\text { car_jeep_van/total no. } \\
\text { of } H^{*} 100\end{array}$ & $\begin{array}{l}\text { Mode of transportation is } \\
\text { important tool for } \\
\text { sustainability. }\end{array}$ & Positive \\
\hline
\end{tabular}

Source: 1 - FSI (2015); 2 - WRIS, http://www.india-wris.nrsc.gov.in; 3 - Census of India, 2011.

\section{Result and discussion}

\section{1. Correlation analysis}

Correlation analysis was done to evaluate the direction and strength of relationship among different sets of indicator (Dahl, 2012). Taking into consideration 27 social, economic and environmental indicators correlation co-efficient was calculated and a correlation matrix was prepared (Table 2). Results from the correlation analysis was grouped into three different categories based on the strength of correlation. The categories defined for correlation analysis were positive feebly correlated, positive moderately correlated, positive strongly correlated and negatively correlated.

Table 2. Categorisation of inter-relationships among different pairs of indicators based on correlation coefficient

Strongly correlated

Primary health

Community health

Secondary schools

Senior secondary schools

LPG/PNG

$$
\mathbf{r}>0.6
$$

Sub-centres

Sub-centres, Primary Health

Primary schools

Primary schools, Secondary schools

Treated tap-water 
Moderately correlated

LPG/PNG

BPL

Metallic road

Feeble correlated

LPG

Tap water

Main workers

Bank

Sub Centre

Negative correlation

Marginal workers

$$
0.5<\mathrm{r}<0.6
$$

Literacy rate

Population density

District hospital

$$
0.4<\mathrm{r}<0.5
$$

Population density

Literacy rate

Treated tapwater

Treated tapwater, LPG

Wasteland

$$
-0.4<\text { r }<0.5
$$

Literacy rate, Main workers, Treated

tap water, LPG

Correlation analysis showed that social and economic indicators were correlated at different levels of magnitude while environmental indicators suffers from data scarcity and is thus inconclusive in nature. Strong correlation is depicted with correlation coefficient ( $\mathrm{r}>$ 0.6). Availability of primary health facility in districts manifested positively on the development of sub-centres and community centres suggesting improvement in health conditions. Interconnectedness among different hierarchical levels in educational was seen with positive association between primary, secondary and higher secondary education. This may have positive effect on the learning outcomes and also on the literacy levels.

Moderate correlation ' $r$ ' ranged from 0.5 to 0.6. With increase in literacy level, use of LPG and PNG for cooking purpose were positively correlated. This may indirectly lessen the dependency on biomass and also improves the air quality. The positive correlation between literacy and LPG/PNG connection may be due to the greater awareness about the government schemes that lead to supply of free cooking gas cylinders for Below poverty line family. Metallic/Pucca road is an important driver of regional development and economic activities. It was moderately correlated with district hospitals. Weak correlation were shown with correlation $r<0.5$ among indicators. Among feebly correlated variables we find, LPG has 
positive yet feeble correlation with population density. This may be attributed to the implementation of recent flagship schemes of central government "Ujjawala” which lead to an steep rise in gas connections and direct benefit transfer schemes for the gas subsidy. However, weaker correlation may be attributed to the remoteness of rural areas wherein regular supply and refilling on a regular basis is still an issue. Clean drinking water facility was also positively associated with the main worker population which indicates a hygienic condition at workplace. When we studied basic infrastructure in any primary and secondary school, we primarily focused on the availability of drinking water. In the present study, there existed a positive relation between drinking water facility and literacy rate. Main workers and tap water were also feebly, yet positively correlated with each other. Working condition was better in place where there was the availability of drinking water facility. Bank and LPG has direct link because of recently introduced schemes of government mandating a bank account for every individual wherein government can directly transfer cash subsidies.

\subsection{Sustainable Development Index}

Performance of 641 districts were evaluated based on the three different parameters individually and finally a composite index i.e. sustainability index was prepared and evaluated for every district.

\section{3. Performance on Social Index}

Among social, the parameters taken into consideration were health, education, demographic and basic amenities (Walker \& Salt, 2006; Wilkinson, 2012a, b). Ensuring healthy life and promoting wellbeing at all age was envisioned as one of the sustainable development goals. Performance of each district on health, education, demographic indicators and available of basic amenities were taken into account. Availability of primary health centres, Community health clinics and districts hospitals are the primary requisite ensuring healthy population (Buffoli et al., 2013). This is intrinsically linked to the reduction in infant mortality rate, maternal health and also sex ratio (Pissourios, 2013).

Educational indicators comprised of literacy rate, number of primary schools, senior schools and senior secondary schools. The goal of sustainability can be achieved by aiming at human resource development, and its initialisation starts from schools (Bevir \& Rhodes, 2006). Basic and primary education is the root for human development and human capital then may act as an engine of economic growth (Laszlo, 2003). For demographic indicators, 
decadal growth rate, sex ratio and population density were taken into consideration (Lélé, 1991; Canadell et al., 2007, Goldin \& Reinert, 2010). Growth rate was an important aspect to understand the pressure exerted on the available natural resources (Canadell et al., 2007). One of the most important publication denoting the problems of growth and providing extrapolations for the future was the book on 'Limits to growth' (Meadows et al., 1972. In 1992, the World Resources Institute argued that alleviation of absolute poverty had a significant impact on sustainable development, since there is a very close cause and effect relationship between poverty, environmental degradation and population growth (Goldin \& Reinert, 2010). Under basic amenities, accessibility of households to treated tap water and LPG for cooking purpose were taken.

Fourteen indicators were chosen for evaluating the performance of different districts in social parameter. Evaluation of performance of districts on social front suggested towards existing steep social gradient between north and south India. A parallel can be drawn with the performance of these states at the economic level (Kwatra et al., 2016). This may be governed by migration pattern which was not taken into consideration in the present study. It can be said that the lack of avenues in the economic sector in north India unfolded as an impediment to the increase in the expenditure on the social sector schemes (Dahl, 2012). This arguments further gains support in the light of strong correlation between the social and economic indicators. Among the south Indian states, performance of Kerala was better compared to other states. This may be attributed to the high remittances received by the government which gives them the leverages to allocate more funds to formulate schemes related to social sectors. Higher remittances, better sex ratio, better literacy rate, all in collaboration have positive influence on the performance of Kerala. While states at lower ladder of performance were mirrored in low sex ratio, lower literacy level, high decadal growth rate, and population density and much dependency on rainfed agriculture, which is common in Indo-Gangetic plains constituting central regions of India (Dahl, 2012).

Overall, it was found that the districts of Northern, South-western and Southern India are very well-off socially. Especially, the districts of some states like Himachal Pradesh and Jammu \& Kashmir and also some districts of Kerala, Karnataka, Maharashtra and Goa have performed relatively better. Very few districts of eastern part of country have performed optimally in social aspect. These regions comprise of northern plains with very fertile soil and perennial source of rivers for water supply (Dahl, 2012). The society are mainly agriculturist but, due to more population pressure and little diversification in the economic 
activities performance on the social parameters remain sluggish. Districts comprising Thar desert like Jaisalmer, Barmer, Jalore of Rajasthan showed poor performance on social parameters due to lack of resources and harsh climate condition. These are some of the region which represents dry region of India with minimal rainfall. Some districts of Punjab and Haryana showed sluggish performance in social criteria due to lower sex ratio in the region. Most of the districts of middle India show moderate development socially. Shravasti, a district in the state of Uttar Pradesh was found to have the lowest value of social index while, Lahul \& Spiti, district of Himachal Pradesh have the maximum value. 


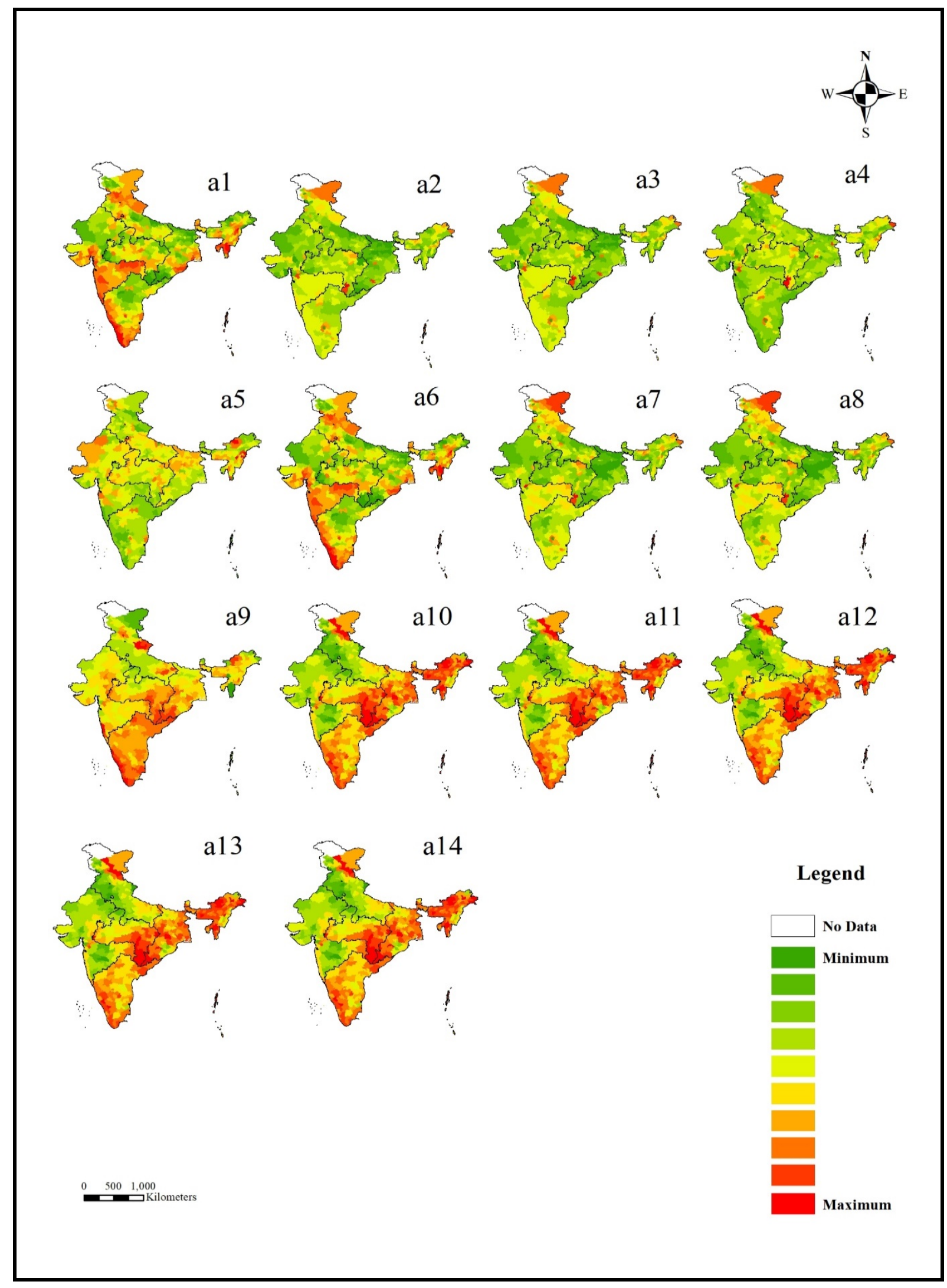

Figure 2. District-wise social indicators of India (Source: FSI (2015); WRIS, http://www.india-wris.nrsc.gov.in; Census of India, 2011) 
In Figure 2 a1 is number of subcentres, a2 is primary health centres, a3 is community health centres, a4 is district hospitals, a5 is literacy rate, a6 is number of primary school, a7 is senior schools, a8 is number of senior secondary schools, a9 is decadal growth rate, a10 is sex ratio, a11 is child sex ratio, a12 is population density, a13 is number of household accessible to treated tap water, a14 is number of household accessible to cooking on LPG/PNG gas.

\section{4. Performance on Economic Index}

Main and marginal workers constitute the important drivers of economic engine of any nation (Ekins, 1997). Workers are categorised as Main and marginal based on the number of working days in an year, with main workers working for more than 180 days and marginal workers working for less than 6 months in an year (Lafferty, 2000). Main workers are generally construed as positive factor for sustainability since it underlines the better working condition and facilities at work places. On the other hand, marginal workers who are basically driven by demand and supply of goods and mostly ephemeral in nature may act as hindrances for economic growth and development (Bevir \& Rhodes, 2006; Sneddon et al., 2006; Sellberg et al., 2015; Jiménez-Aceirtuno et al., 2020). Ensuring better working conditions and creating a viable employment opportunity may serve as a boon for India since more than $65 \%$ of population is constituted by an age group with age below 35 . This may help India to reap the benefit of demographic dividend. Infrastructure such as construction of all-weather roads, electricity connection, banking services and mode of transportation such as two-wheeler and four wheeler are also the important features for economic development interwined with social development.

Eight indicators have been taken for evaluating economic performance of the districts, which included categorisation of workforce, population lying Below poverty line (BPL), infrastructure and transport. Best performance on economic front were seen in the districts in and around Deccan plateau region of India. These region are mineral-rich as well as most of the companies from service sectors such as information technology (ITs) sectors, business processes and outsourcing (BPO) are located here. Agriculture emerged as a dragging force since most of the districts which are at lower ladders in terms of economic performance were mostly dependent on agricultural activities in our study. It may be said that the benefits of the green revolution were more concentrated in few states and as a result may have resulted in disparity in agriculture practices and agriculture-related activities. Some of the states like Punjab and Haryana are showing better performance in terms of economic 
parameters compared to other states which suggests the diversification of economic activities supplementing the income from primary sector (Kwatra, 2016). The Lowest performance were seen in the districts which are untouched by the green revolution and were still following traditional agricultural practices and more or less dependent on Indian summer monsoon for irrigation. The agricultural infrastructure in these regions were also lacking compared to the states of Punjab and Haryana. In the future climate change scenario, with the increase in extreme events such as flood, heavy precipitation, drought, districts in the states like Bihar, UP are more economically and thus socially fragile compared to the districts which has diversification in the economic activities.

Economically, the Northern, Western and Southern districts of the country are very well off. Central, Eastern and north eastern parts of the country still lag behind in terms of economic development even though, some districts of Arunachal Pradesh are very well of. This may be due to low population density seen in the districts of Arunachal Pradesh. Hyderabad may not perform well in environmental indicator but was well-developed economically and Garhwa, a district of Jharkhand showed the least development on economic parameters. Districts along the western coast are more developed compared to the eastern coast. This may be due to the more number of ports along the western coast and also number of tourists-spots in these regions.

\section{5. Performance on Environmental Index}

The environmental Kuznets curve (Ekins, 1997) suggests that the economic development in the initial stage may often leads to the environmental degradation. After achieving certain level of economic growth the relation between society and environment is improved, reducing the level of environmental degradation (Stern, 2004). Henceforth suggesting a scope of reconciliation economic growth and environment only after attainment of certain level of economic growth. For evaluation of performance of districts at environmental parameter, indicators that were taken into account included forest cover, scrub, wasteland, biodiversity and ground water. There is a data constrain for assessing environmental performance at the district level that suggest an improvement in the scope of considering environment in policy planning and development.

It is found that except in the hilly states of Himalaya, districts of Western Ghats, Uttarakhand and few districts of Chattisgarh (Bastar and Dantewada) and Jharkhand with better forest cover performed well in terms of environmental parameters. Most of the districts 
of Andhra Pradesh and Telangana although may have performed well from economic point of view but are at lower ladders of performance in terms of environmental development. This may be due to the deterioration in environment due to ongoing mining activities in these regions. The prime example is the district of Hyderabad which has although performed very well in terms of economic parameters but were unable to perform well on the environmental front. Western districts consisting of desert areas like Rajasthan, Gujarat also showed poor performance on environmental front. This may be attributed to the natural environmental condition and very less to no monsoonal precipitation. Our study suggests that there is a need and scope of urban forestry which is one of the objective in 12th five year plans which focuses on increasing green cover by 1 million hectare every year. This may bring positive result in terms of mitigating urban heat island, urban flood and may help in recharge of ground water. 


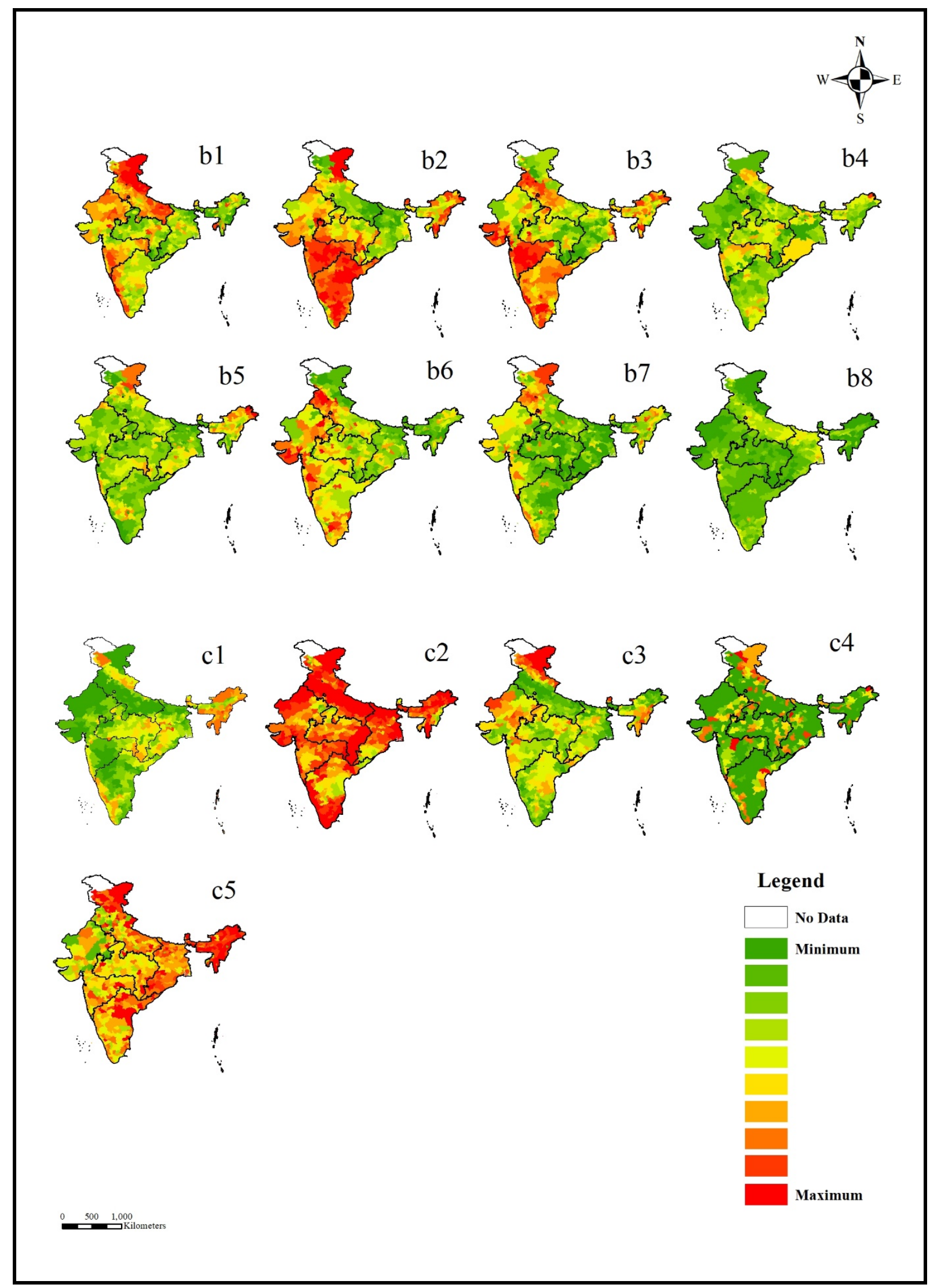

Figure 3. District wise economic and environmental indicators of India (Source: FSI (2015); WRIS, http://www.india-wris.nrsc.gov.in; Census of India, 2011) 
In Figure 3 b1 is main workers, b2 is marginal workers, b3 is rural household below poverty line, b4 is pakka road, b5 is number of household accessible to electricity, b6 is number of household accessible to bank services, b7 is two wheeler, and b8 is four wheeler. C1 is percent forest cover, c2 is percent scrub cover, c3 is total wasteland, c4 is percent protected land, and c5 is ground water in metres.

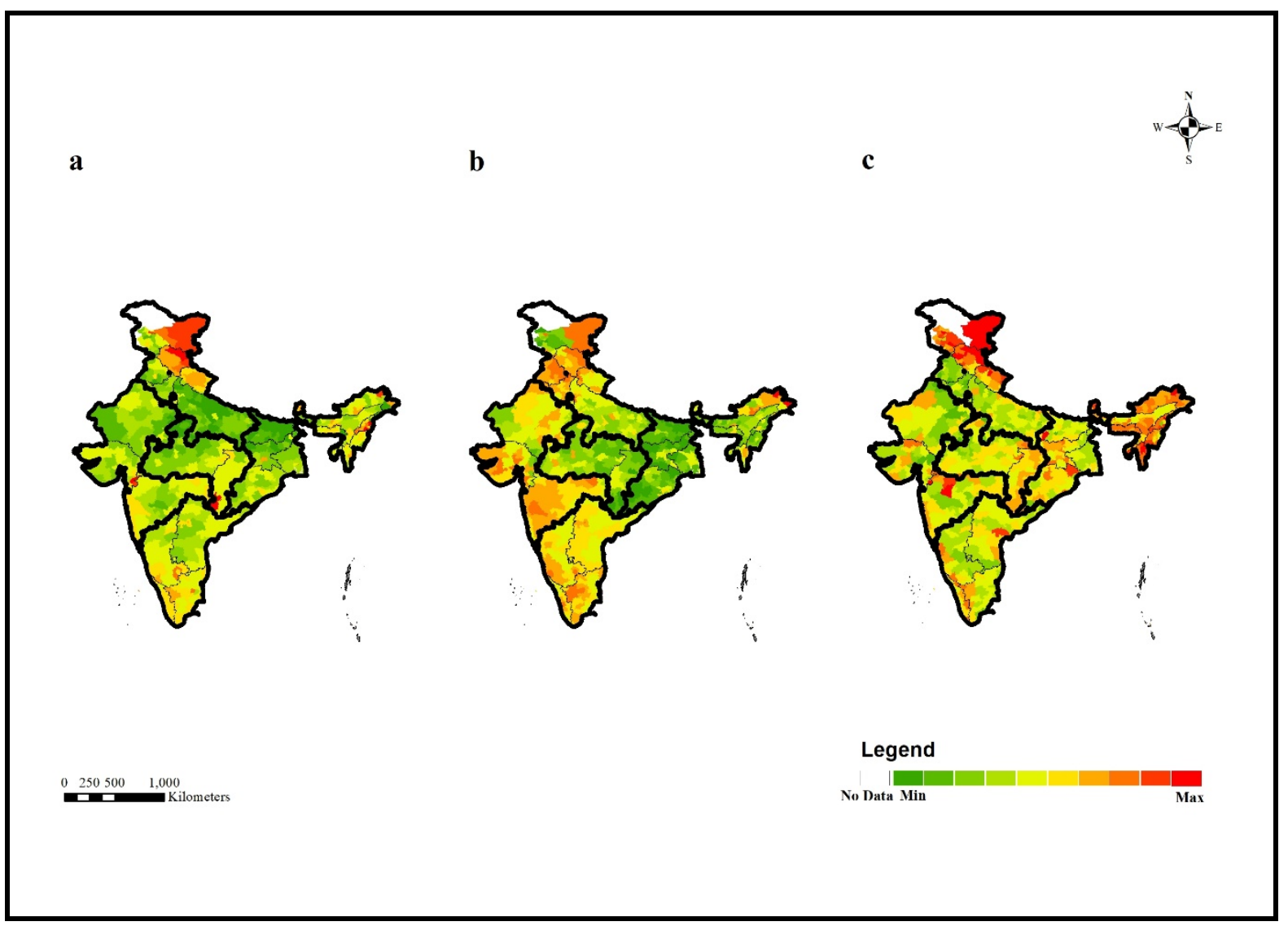

Figure 4. District wise average social, economic and environmental performance of India. (Source: FSI (2015), WRIS, http://www.india-wris.nrsc.gov.in; Census of India, 2011). Here, $\mathrm{a}=$ social, $\mathrm{b}=$ economic and $\mathrm{c}=$ environmental performance

\section{6. Performance on Sustainable Development Index (SDI)}

Sustainability Development Index which is a composite index calculated after averaging all the three indices (Taylor, 2002). The analysis of the SDI reveals that southern states of India are ahead than central and eastern part of the country. The northern part of the country comprising hilly states of Jammu and Kashmir, Uttarakhand, and Himachal Pradesh has better performance in SDI. The facts which is to be noted are that the districts from smaller states have performed well in terms of sustainability. This may be due to the smaller states may also lead to better administration in terms of resource management and planning. 
Overall, the districts of Northern and Southern India, which are very well in all three domain, namely social, environmental and economic showed better results of SDI. The eastern states did not performed well on sustainability front barring, few districts of Arunachal Pradesh. This may be primarily attributed to the lack of economic activities. Western districts, which although performed well in terms of economic development, lagged behind in overall index due to less stress on environment development. Districts of central India, including districts of Odisha, Madhya Pradesh, Andhra Pradesh, Bihar, Uttar Pradesh, which lag behind in all the three parameters showed poor SDI. Himalayan states showed better performance in SDI and smaller states and UT's of Goa and New Delhi also showed better performance on Sustainability index. The plausible reason could be smaller administrative boundaries of Himalayan state and Goa, New Delhi which lead to better performance 


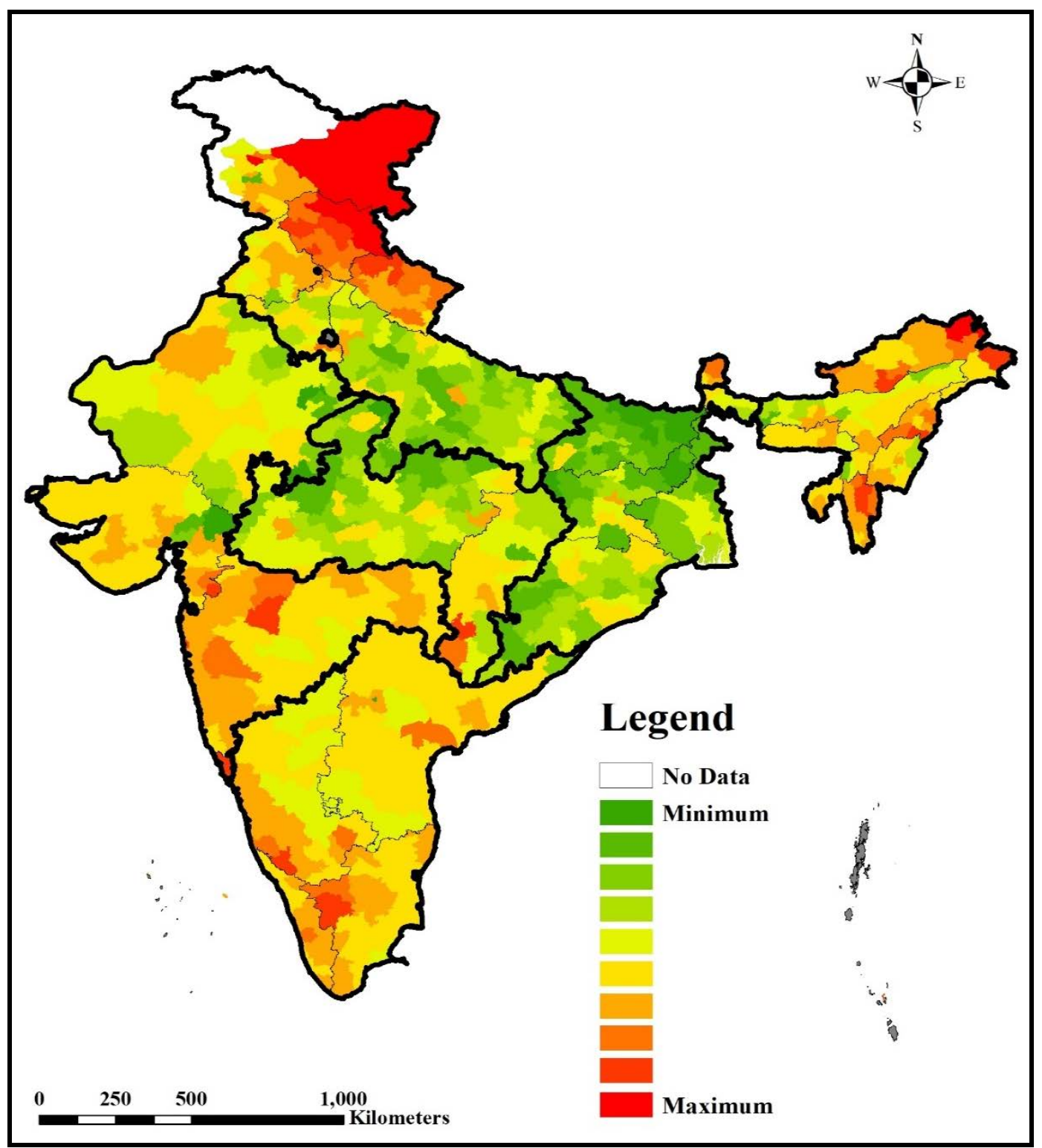

Figure 5. District wise Sustainable Development Index of India (Source: FSI (2015); WRIS, http://www.india-wris.nrsc.gov.in; Census, 2011)

\section{Conclusion}

Overall, after a comprehensive analysis of the available data from the 641 districts it may be said that the performance of districts on SDGs varied at regional levels. Unfortunately, environment is still an important component missing or not stressed optimally in policy planning. As a result, most of the districts suffer from data redundancy in the environmental parameter. Our results also suggest a scope of second wave of green revolution particularly in the region which previously remained untouched. Infrastructure development such as Coldstorage facilities for storing perishing vegetables, innovative agricultural practices, construction of canals and climate resilient agriculture with diversification $\mathrm{n}$ agricultural 
crops may help in improving the economic performance of the districts. Financial incentivisation in terms of Universal basic income or schemes like Universal health coverage may help a larger population to come out of poverty traps and improve the performance of districts and state as whole on SDGs. Our study may help in micro-level planning at district levels and may help in raising public and policy support, realignment and reorientation of the existing policy from the perspective of SDGs. The outcome may have local, regional and national implications. Additionally, it may help in mitigating various impediments related to fragmented data and various challenges in achieving SDGs. For actual realization of sustainable goals, proper coordination and reconciliation among all the parameters is necessary.

\section{Acknowledgement}

PT acknowledge the support provided by Prof. P.K. Joshi (School of Environmental Sciences, JNU) in preparation of the manuscript.

\section{References}

Bai X., McAllister R.R.J., Beaty R.M. \& Taylor B., 2010, Urban policy and governance in a global environment: complex systems, scale mismatches and public participation. Current Opinion in Environmental Sustainability 2: 129-135. http://dx.doi. org/10.1016/j.cosust.2010.05.008

Bandura R., 2008, A survey of composite indices measuring country performance: 2008 update. United Nations Development Programme, Office of Development Studies (UNDP/ODS Working Paper), New York.

Bevir M. \& Rhodes R.A.W., 2006, Governance stories. Routledge, London, UK.

Biggs H., Ferreira S., Freitag-Ronaldson S. \& Grant-Biggs R., 2011, Taking stock after a decade: does the 'thresholds of potential concern' concept need a socio-ecological revamp? Koedoe 53:2. http://dx.doi.org/10.4102/koedoe.v53i2.1002

Biggs H.C. \& Rogers K.H., 2003, An adaptive system to link science, monitoring, and management in practice, [in:] J.T. Du Toit, K.H. Rogers, H.C. Biggs (eds) The Kruger experience: ecology and management of savanna heterogeneity. Island Press, Washington, DC, pp. 59-80.

Bossel H., 1999, Indicators for Sustainable Development: Theory, Method, Applications. International Institute for Sustainable Development, Winnipeg, Manitoba, Canada.

Buffoli M., Capolongo S., Bottero M., Cavagliato E., Speranza S. \& Volpatti L., 2013, Sustainable Healthcare: how to assess and improve healthcare structures' sustainability. Annali di igiene 25(5): 411-418. doi: 10.7416/ai.2013.1942

Canadell J.G., Le Quéré C., Raupach M.R., Field C.B., Buitenhuis E.T., Ciais P., ... \& Marland G., 2007, Contributions to accelerating atmospheric CO2 growth from economic activity, carbon intensity, and efficiency of natural sinks. Proceedings of the National Academy of Sciences 104(47): 18866-18870.

Census of India, 2011, Government of India. http://censusindia.gov.in/ 
Dahl A.L., 2012,. Achievements and gaps in indicators for sustainability. Ecological Indicators 17: 14-19.

De J.R., 1992, United Nations Conference on Environment \& Development Rio de Janerio, Brazil, 3 to 14 June 1992. Reproduction, 351(10.1007).

Ekins P., 1997, The Kuznets curve for the environment and economic growth: examining the evidence. Environment and Planning A 29(5): 805-830.

FSI, 2015, India State of Forest Report 2015. Forest Survey of India, Ministry of Environment, Forest \& Climate Change, Dehradun.

Glaser G., 2012, Base sustainable development goals on science. Nature 491(7422): 35-35.

Goldin I. \& Reinert K.A., 2010, Ideas, development, and globalization. Canadian Journal of Development Studies 29(3-4): 329-348.

Hák T., Janoušková S. \& Moldan B., 2016, Sustainable Development Goals: A need for relevant indicators. Ecological Indicators 60: 565-573.

Harris J.M., 2000, Basic principles of sustainable development, [in:] R. Seidler, K.S. Bawa, (eds), Dimensions of Sustainable Development. Tuft University, Medford, MA, USA, pp. 21-41.

Jiménez-Aceituno A., Peterson G.D., Norström A.V., Wong G.Y., \& Downing A.S., 2020, Local lens for SDG implementation: lessons from bottom-up approaches in Africa. Sustainability Science 15: 729-743. https://doi.org/10.1007/s11625-01900746-0

Kates R.W., Parris T.M. \& Leiserowitz A.A., 2005, What is sustainable development? Goals, indicators, values, and practice. Environment (Washington DC) 47(3): 8-21.

Kwatra S., Kumar A., Sharma P., Sharma S. \& Singhal S., 2016, Benchmarking sustainability using indicators: An Indian case study. Ecological Indicators 61: 928-940.

Lafferty W.M. \& Meadowcroft J., 2000, Implementing Sustainable Development: Strategies and initiatives in high consumption societies. Oxford University Press, Oxford, UK. doi: 1093/0199242011.003.0001

Laszlo C., 2003, The sustainable company: How to create lasting value through social and environmental performance. Island Press, Washington, DC.

Le Blanc D., 2015, Towards integration at last? The sustainable development goals as a network of targets. Sustainable Development 23: 176-187.

Lélé S.M., 1991, Sustainable development: a critical review. World Development 19(6): 607621.

Meadows D.H., Meadows D.L., Randers J. \& Behrens W.W., III, 1972, The Limits to Growth: A eport for The Club of Rome's project on the predicament of mankind. A Potomac Associated Book, Universe Books, New York.

Mebratu D., 1998, Sustainability and sustainable development: historical and conceptual review. Environmental Impact Assessment Review 18(6): 493-520.

Pissourios I.A., 2013, An interdisciplinary study on indicators: A comparative review of quality-of-life, macroeconomic, environmental, welfare and sustainability indicators. Ecological Indicators 34: 420-427.

Sellberg M.M., Wilkinson C. \& Peterson G.D., 2015, Resilience assessment: a useful approach to navigate urban sustainability challenges. Ecology and Society 20(1): 43.

Sneddon C., Howarth R.B. \& Norgaard R.B., 2006, Sustainable development in a postBrundtland world. Ecological Economics 57(2): 253-268.

Stern D.I., 2004, The rise and fall of the environmental Kuznets curve. World Development 32(8): 1419-1439.

Taylor J., 2002, Sustainable development: A dubious solution in search of a problem. Cato Policy Analysis Series, No. 449. The Cato Institute, Washington, DC. 
WCED, 1987, World Commission on Environment and Development: Our common future. Oxford University Press, Oxford, UK.

Walker B. \& Salt D., 2006, Resilience thinking: sustaining ecosystems and people in a changing world. Island Press, Washington, DC.

Wilkinson C., 2012a, Urban resilience: what does it mean in planning practice? Planning Theory and Practice 13(2): 319-324. http://dx.doi.org/10.1080/14649357.2012.677124

Wilkinson C., 2012b, Social-ecological resilience: insights and issues for planning theory. Planning Theory 11(2): 148-169. http:// dx.doi.org/10.1177/1473095211426274

WRIS, Water Resources Information System. Government of India. http://www.indiawris.nrsc.gov.in 